will not be impaired by the tests. The proposed series of tests will investigate the effects of firing charges at greater depths, and of greater size than is possible in the Kit Hill mine. Precautions will be taken to ensure that there will be no surface disturbance or damage. It is planned to register the results on seismic instruments at various distances from the mine. Local authorities and other interests concerned are being consulted and planning permission is being sought.

\section{British Neutron Source Thermal Reactor}

THE United Kingdom Atomic Energy Authority has signed a contract with the Hawker Siddeley Nuclear Power Co. for the purchase of a reactor to be installed at the Atomic Energy Establishment, Winfrith, Dorset, to be in operation by December 1960. Contracts for shielding, and other equipment associated with the reactor, are being placed. The reactor, which will be known as Nestor (Neutron Source Thermal Reactor), is based upon the Company's Jason reactor. Its purpose will be to provide the neutrons required for the experimental assemblies of nuclear fuels and moderators which are used to obtain data for the design of future reactor systems. To meet the requirements of the Authority, the Jason reactor has been modified to be capable of continuous operation at a power of up to $10 \mathrm{~kW}$. and its layout has been altered so that it can drive up to five experimental assemblies simultaneously. Details of the modifications have been worked out in collaboration between the Authority and the Com. pany. The nuclear fuel in Nestor is an alloy of highly enriched uranium and aluminium arranged in an annulus. Natural water is used both as coolant and moderator. The reactor is capable of operation of $10 \mathrm{~kW}$. giving a thermal neutron flux of $10^{11}$ neutrons per cm. ${ }^{2}$ per sec. in the centre of the core and of up to $10^{8}$ neutrons per cm. ${ }^{2}$ per sec. in typical assemblies. The thermal neutron flux can be varied by altering the reactor power-level, by using neutron shutters or by arranging the fuel loading in the annular core.

\section{Dungeness and the Nature Conservancy}

IN the light of the Government's recent decision to consent to the construction of a large nuclear power station on Dungeness, the Nature Conservancy states that the direct and indirect repercussions of the power station on the remaining area show conclusively that the future scientific interest will be too much reduced to qualify it for the status of a national nature reserve. The proposed Dungeness National Nature Reserve is accordingly abandoned and the negotiations for it will not be pursued. The Conservancy will not, however, cease to concern itself with the preservation of such assets as can still be saved. For this purpose the undeveloped area (apart from that section now compulsorily purchased by the Central Electricity Generating Board) will remain designated by the Nature Conservancy under Section 23 of the National Parks and Access to the Countryside Act, 1949, as a 'site of special scientific interest', and the Conservancy will accordingly continue to be consulted about any further development which may be proposed for any other parts of the area. The Conservancy will in particular welcome and encourage any measures which the Royal Society for the Protection of Birds may be able to take for maintaining and defending the fauna and flora and, in particular, the bird-life of the 1,234 acres of shingle which it owns between the power station site, the Lydd Army Ranges and the bungalow settlement. If Kent naturalists wish to attempt further salvage work in the remaining area of the 'site of special scientific interest' they will have the Conservancy's support. The Conservancy will continue to keep in touch with the Central Electricity Generating Board and its contractors with the view of minimizing destruction of scientific interest over the area surrounding the power station site.

\section{Field Studies}

Ansual reports of the Field Studies Council have recorded accounts of scientific investigations which have been made in areas surrounding the Council's field centres in Pembrokeshire, Suffolk, Surrey, Yorkshire, Salop and Devon. The growth of these centres and the increasing amount of original work which is being carried out at them have made it impossible to publish anything but a small part of the material available. The Council has now decided to issue an additional publication about new knowledge being gained in field-studies connected with archæology, botany, geography, geology and zoology. "Field Studies" will appear once yearly and, in time, it is hoped that the series of papers published for each centre will have grown into a thorough local survey. The first issue ("Field Studies", Vol. 1, No. 1 (May 1959). Copies obtainable from the Publicity Secretary, Field Studies Council, Ravensmead, Keston, Kent. 5s.) describes the birds, land-use, farm practice, and climate of parts of the Dale peninsula; the land snails of Flatford; the geomorphology of the Tillingbourne; stratigraphy and pollen analysis of Malham Tarn and Tarn Moss ; the geography of the Alberbury Breccia; and freshwater studies in the Shropshire Union Canal.

\section{The Young Darwin}

To mark the hundredth anniversary of the publication of Darwin's "Origin of Species", a commemorative oration was delivered by Prof. C. F. A. Pantin at Christ's College, Cambridge, on September 29 "'Young Darwin and the 'Origin of Species'." By Dr. C. F. A. Pantin. Pp. 17. Cambridge: Christ's College, 1959). The address was noteworthy for a number of features. Attention was concentrated not on an old man suffering from ill health but on the pleasant, virile young man who went up to Christ's College in 1828 to prepare himself for the Church; the reasons for Darwin's subsequent ill health were also examined by Prof. Pantin, who suggested that this may have been due not to any suppressed psychological antagonisms towards his father, but to the hardships and rigours encountered during the fiveyear voyage on H.M.S. Beagle, a 10 -gun brig of only 242 tons. Darwin's contributions to knowledge in many branches of natural history include references to the origins of coral soas. There are also some valuable gleanings of the way in which "The Origin of Species" emerged.

\section{The London Mathematical Society}

THE annual general meeting of the London Mathematical Society was held on November 19 at Bur. lington House. The De Morgan Medal was presented to Sir William Hodge, physical secretary of the Royal Society and Master of Pembroke College, Cambridge. In presenting the Medal, the president (Prof. $H$. 